a světovou literaturu. Kolokvium přispělo $\mathrm{k}$ prohloubení spolupráce mezi doktorandy a akademickými pracovníky zabývajícími se osobností a tvorbou F. M. Dostojevského.

Lenka Paučová

https://doi.org/10.5817/NR2019-1-13

\section{Dialog kultur oslavil jubileum}

Jubilejní desátý ročník oslavila mezinárodní vědecká konference Dialog kultur, která se uskutečnila ve dnech 15 . a 16. ledna 2019 na Pedagogické fakultě Univerzity Hradec Králové. O organizaci se již tradičně postarala Katedra ruského jazyka a literatury ve spolupráci se Slavistickou společností Franka Wollmana a s Českou asociací rusistů.

Konferenci zahájila prorektorka UHK pro tvůrčí činnost Mgr. Leona Stašová, Ph.D., podporu ze strany PdF UHK vyjádřila proděkanka pro internacionalizaci a praxe Mgr. Daniela Vrabcová, Ph.D. Za pořadatele pomluvila vedoucí KRJL PdF UHK Mgr. Jana Kostincová, Ph.D., na niž navázal předseda Slavistické společnosti Franka Wollmana prof. PhDr. Ivo Pospíšil, DrSc. Úvodní část konference zakončil předseda České asociace rusistů Mgr. Jiř́ Klapka, který zpestřil program hudební vložkou a představením vzácných textů z nových hudebních sborníků.

Na letošním Dialogu kultur se zase jednalo ve třech sekcích - v literárněvědné, lingvistické a lingvodidaktické. Literární vědci a vědkyně se $\mathrm{v}$ tomto roce zaměřili na problematiku slovanských literatur a podob performance a řešili množství aktuálních otázek jako např́ílad téma paměti v ruské a české literatuře, tvorba J.S. Machara v souvislosti s ruskou literaturou, prredstavovali performanci $\mathrm{v}$ kontextu divadla a konceptuální literatury aj.

V oblasti lingvistiky se rokovalo o cizojazyčných vlivech na slovanské jazyky na různých úrovních jazykového systému. Mimo jiné se řešily otázky silných a slabých stránek korpusu Intercorp a možností jeho použití $v$ prèekladatelské práci, precedentní fenomény z oblasti sportu, řešila se translatologická problematika (např́klad práce s terminologií v oblasti sociální sféry), vzpomínalo se na znakové osobnosti v lingvistice a stále aktuální diskuze o ruském jazyce na začátku 21. století aj.

Současné téma bylo rozvíjeno i v lingvodidaktické sekci, ve které se zabývalo moderními tendencemi $\mathrm{v}$ didaktice ruského jazyka. Zde účastnici diskutovali na témata používání vokální tvorby ve výuce fonetiky, lexiky a gramatiky, efektivního využití videomateriálu při výuce praktického jazyka, zpracování nových učebních materiálů, uměleckého textu jako výukového materiálu na hodinách ruského jazyka.

$\mathrm{Na}$ Dialogu kultur se svými príspěvky vystoupilo 50 odborníků a odbornic v oblastech lingvistiky, literární vědy a didaktiky, přičemž několik dalších kolegů a kolegyň přicestovalo i ze zahraničí bez 
vlastních příspěvků s cílem zapojit se do diskuzí o jednotlivých referátech. Díky skvěle až velkoryse časově rozvrženému programu vždy byl dostatek prostoru na odborné diskutování, které v každé ze sekcí proběhlo velice živě, produktivně a emotivně.

Vyjma domácího pracoviště rozsah své vědecko-výzkumné činnosti představil Ústav slavistiky Filozofické fakulty Masarykovy univerzity v Brně, odkud přijela nejhojnější delegace. Zastoupena byla i další rusistická a slavistická pracoviště z významných českých univerzit, at už se jednalo o Katedru ruského jazyka a literatury na Pedagogické fakultě MU v Brně, Katedru slavistiky Filozofické fakulty Univerzity Palackého v Olomouci, Katedru slavistiky Filozofické fakulty Ostravské univerzity, Ústav východoevropských studií Filozofické fakulty, Katedru rusistiky a lingvodidaktiky Pedagogické fakulty a Centrum jazykové př́pravy Matematicko-fyzikální fakulty Univerzity Karlovy i Katedru ruského a francouzského jazyka Fakulty pedagogické Západočeské univerzity v Plzni. Zastoupení na konferenci měla také Katedra marketingové komunikace Fakulty ekonomických studií Vysoké školy finanční a správní i Centrum pro studium demokracie a kultury.

Ze zahraničních pracovišt na Dialog kultur $X$ zavítali badatelé ze Slovenska (Slovenská akademie věd v Bratislavě a Univerzita Konštantína Filozofa v Nitře), z Polska (Slezská univerzita v Katovicích, Varšavská univerzita), z Rakouska (Univerzita Innsbruck) i z Ruska
(Tomská státní univerzita, Moskevská pedagogická státní univerzita, Kubáňská státní univerzita v Krasnodaru, Sankt-Petěrburgská státní univerzita, Ruská technologická univerzita v Moskvě, Národní výzkumná Nižegorodská státní univerzita N. I. Lobačevského v Nižním Novgorodu a další).

Otevřená a přátelská atmosféra konference vybízela $\mathrm{k}$ neustálým a velmi věcným a živým diskuzím i mezi zasedáními sekcí. Zakladatel konference prof. PhDr. Oldřich Richterek, CSc., při přípitku též vzpomenul na skromné začátky setkávání na půdě $\mathrm{PdF}$ UHK při prvním ročníku Dialogu kultur v roce 2002.

Jedinečnou a velmi krásnou tradicí na Dialogu kultur je vždy všemi účastníky očekáváné představení studentské divadelní skupiny Inspirace, které ani letos nezklamalo. Pod neměnným režijním vedením doc. Galiny Kosych, CSc., nazkoušela skupina studentů hru Aleхаndra Ivanoviče Pisareva Хлопотун, или дело мастера боится, která byla předvedená velmi expresivně, vesele a skoro profesionálně. Nechyběly zde ani působivé kulisy, výrazné dobové kostýmy či živý hudební doprovod. Velký obdiv si zaslouží mladí herci, kteří zvládli nacvičit a předvést hru v jazyce originálu a prožít u toho skutečné emoce.

Na konferenci byl kromě sborníku některých prríspěvků $z$ literárněvědné sekce z předchozího ročníku konference představen také vizuál prvního čísla časopisu Philologia Rossica, který bude od tohoto roku KRJL PdF UHK vydávat 
ve spolupráci s Nakladatelstvím Pavel Mervart. Hlavní redaktor časopisu a zároveň předseda organizačního výboru konference PhDr. Jindřich Kesner, CSc., vyzval účastníky a účastnice konference k participaci na obsahu druhého čísla časopisu, které bude vydáno ještě letos. Výstupem letošní konference se má také stát sborník př́spěvků účastníků jubilejního desátého Dialogu kultur.

Jaroslav Sommer - Polina Zolina

https://doi.org/10.5817/NR2019-1-14

\section{Konference Hodnoty v literatuře a v umĕní počtvrté}

Když se v roce 2012 konala první konference o hodnotách v literatuře a v umění pořádaná společně Ústavem slavistiky Filozofické fakulty Masarykovy univerzity a Českou asociací slavistů, šlo o malý test, nakolik může být takové téma zajímavé $\mathrm{v}$ době, kdy vrch zdánlivě berou postmoderní tendence hodnoty nivelizovat a stírat, kdy připomenout je znamená málem něco jako návrat $\mathrm{k}$ ruinám památek středověku. Zájem ovšem byl, byla i ochota organizátorů pokračovat. Následovaly konference v letech 2014 a 2016 - a vytvořilo se „jádro“ těch, kteř́i přijížděli opakovaně a měli zájem $\mathrm{v}$ diskusi o hodnotách pokračovat. Ve dnech 29.-30. srpna 2018 se konala takto tematicky pojatá konference již počtvrté a s rekordním zájmem o účast v ní.

Čtvrtý ročník konference využil toho, co se osvědčilo již v jejím předchozím běhu: mimo relativně volně pojaté panely zařadil i panely orientované tematicky na tvorbu V. M. Garšina, I. S. Turgeněva a pak také na dva obecněji pojaté okruhy, v nichž bylo možno se zaměřit na axiologické aspekty odrazu občanské války 1918-1922 v literárních dílech a na axiologické otázky ruské literární kritiky 19. století.

Konference se osobně zúčastnilo na šedesát badatelů ze Slovenska, Ruska, Polska, Izraele, Madarska, Německa, Gruzie, Běloruska, Ukrajiny, Bulharska a Kazachstánu, přičemž řada dalších zájemců poslala svá vystoupení v písemné podobě, protože jim osobní, termínové či finanční okolnosti neumožnily prijet.

Sám program konference, kterou hostila Filozofická fakulta Masarykovy univerzity, probíhal v celkem devíti sekcích orientovaných především na ruskou literaturu 19. a 20. století, výrazný vzestup zájmu bylo možno ale vidět i v sekci věnované jiným evropským literaturám a sekci, která sledovala „vyzařování" literatury směrem k jiným druhům umění a $\mathrm{k}$ výchovné, resp. školské praxi.

Jednání jednotlivých sekcí zahrnovala tematicky blízké okruhy spjaté zájmem o zachycení celé řady dílčích hodnotových aspektů, prričemž akcentovány byly otázky především etického, filozofického a uměleckého charakteru, prosazovaly se 